3-1-2018

\title{
Innovators and Implementers: The Multilevel Politics of Civil Society Governance in Rural China
}

Sara A. Newland

John F. Kennedy School of Government, snewland@smith.edu

Follow this and additional works at: https://scholarworks.smith.edu/gov_facpubs

Part of the Political Science Commons

\section{Recommended Citation}

Newland, Sara A., "Innovators and Implementers: The Multilevel Politics of Civil Society Governance in Rural China" (2018). Government: Faculty Publications, Smith College, Northampton, MA.

https://scholarworks.smith.edu/gov_facpubs/27

This Article has been accepted for inclusion in Government: Faculty Publications by an authorized administrator of Smith ScholarWorks. For more information, please contact scholarworks@smith.edu 


\title{
Innovators and Implementers: The Multilevel Politics of Civil Society Governance in Rural China
}

\author{
Sara A. Newland ${ }^{*}$
}

\begin{abstract}
Early literature on China's civil society focused on organizations' autonomy from the state. However, the precise ways in which these organizations are dependent on the state - and on individual officials - are less well understood. I argue that NGOs depend on different types of officials whose career incentives vary, with significant implications for relationships with non-state actors. One set of officials, innovators, seeks rapid promotion and uses civil society partnerships to gain higher-level attention. Innovators' career goals lead them to provide support for NGOs; however, excessive reliance on innovators can force organizations to stray from their mission and can weaken their long-term position in a given locality. A second set of officials, implementers, seeks stability and security. Cognizant of the risks of partnering with non-state actors, these officials are sometimes forced by their superiors to engage with NGOs but see little personal benefit in doing so. These findings suggest the importance of China's multilevel political structure for state-society relations.
\end{abstract}

Keywords: civil society; NGOs; multilevel politics; cadre management; rural China; public services

Do civil society organizations in China represent an autonomous sphere independent from the state and, consequently, a nascent source of democratic opposition to Chinese Communist Party (CCP) rule? Much of the literature on NGOs in China has focused on this debate. ${ }^{1}$ However, some question the wisdom of doing so, arguing that research on Chinese civil society has become excessively narrow in scope, that an autonomous civil society is an unattainable standard, or that it would be better to look for analogues within China's own history than to import foreign models. ${ }^{2}$ Indeed, although some organizations seek to

* Ash Center for Democratic Governance and Innovation, Kennedy School of Government, Harvard University. Email: Sara_Newland@hks.harvard.edu.

1 Foster 2001; Hsu, Jennifer, and Hasmath 2014; Read 2003; Teets 2013; Unger 2008; Zhang, Xin, and Baum 2004

2 Perry 1994; Salmenkari 2013; Tenzin 2014. 
avoid the state, autonomy may not even be a desirable goal for many NGOs, as it comes at the cost of influence. ${ }^{3}$ And, while autonomy is a central concern of Western research on NGOs in China, organizations themselves see autonomy as less important than efficacy and "organizational viability."

These challenges to the notion of autonomy suggest the importance of shifting our focus from organizational autonomy to organizational dependence. In other words, if autonomy is neither possible nor necessarily desirable, how do organizations interact with and depend on the state? And, given that the party-state is characterized by what Kenneth Lieberthal and David Lampton call "fragmented authoritarianism," 5 on whom, exactly, do NGOs depend? Answering these questions requires us to assess organizations' actions and motivations, but also to pay greater attention to the range of state actors these organizations encounter and the incentives these officials face.

It has been well established that officials at different levels of China's geographic-administrative hierarchy have different goals, which may lead them to cooperate in some instances and work at cross purposes in others. ${ }^{6}$ The relevance of these formal political networks for the more informal ties between officials and NGOs has not been explored, however. I argue that the structure of the Chinese state has important implications for non-state organizations, which must navigate between different levels of government and different individuals within those levels whose goals do not necessarily align. In short, organizations must navigate two types of local state hierarchies. The first is the tiaolkuai 条块 system of vertical and horizontal networks that structures the party-state. The second is a hierarchy of different individual officials embedded within this institutional framework, a result of the multilevel structure of the Chinese state and of the monitoring and promotion system (the cadre responsibility system) used to incentivize officials to follow higher-level mandates.

As they navigate these hierarchies, NGOs encounter two very different types of officials. The first type is ambitious and promotion oriented. These officials, whom I label innovators, are eager to use partnerships with non-state service providers to boost their own promotion prospects and may provide various forms of assistance, such as material resources, access to their professional network of other officials, or information about the locality the NGO hopes to serve, to help improve an organization's odds of success. Innovators' support for non-state organizations may be principled, but it is also instrumental. By partnering with non-state actors to provide public services, these officials hope to earn a reputation for innovation that will impress their superiors and lead to promotion to higher office.

Partnerships between these innovators and non-state organizations can be mutually beneficial. However, non-state organizations pay a price for depending

6 Heberer and Schubert 2012; Lieberthal and Lampton 1992; Mertha 2009; Smith 2010. 
too heavily on such partnerships. First, these leaders are likely to be only temporary residents. The same qualities that make them effective partners for non-state organizations also lead them to move quickly up the promotion ladder, which often takes them to a different locality every five to eight years. Thus, while a partnership with an innovator can yield invaluable short-term benefits, investing too heavily in this relationship can leave organizations in a precarious position when their patron moves on to a different post. Second, promotion-minded officials' career incentives lead to spatial biases in the quality of local governance, with important implications for civil society organizations as well as for local government projects. Promotion incentives encourage officials to focus on physically proximate areas that are likely to be observed by their superiors. ${ }^{7}$ This logic can lead them to push NGOs into geographically proximate locations that are easy for higher-level elites to reach, even when an organization's express purpose is to serve underserved areas.

The second group of officials I term implementers. These officials seek to minimize political risk and any extra work for which they are unlikely to be rewarded. Some spend much of their time engaged in direct contact with citizens and state-run public service providers. Others are long-time employees of a single bureau and have amassed substantial knowledge of the relevant policy area but may have little day-to-day professional contact with citizens. Unlike innovators, implementers do not seek to draw attention to themselves, as doing so can come at a high cost to their career if a gamble does not pay off. While the role of promotion incentives in motivating official behaviour has received substantial attention from scholars of rural Chinese politics, ${ }^{8}$ many officials are uninterested in promotion, preferring the stability of a low-stress job in or near their hometown. ${ }^{9}$ While some such officials become committed to the mission of a non-state organization, they have little professional incentive to spend time and energy assisting these organizations. And, because such assistance is typically outside the purview of the implementers' formal job responsibilities, higher-level innovators are limited in their ability to force these implementers to enthusiastically support civil society projects. In short, the principal-agent problems within the multilevel Chinese state that disrupt formal policy implementation create challenges for non-state actors as well.

Drawing on in-depth interviews as well as non-participant observation of two groups" activities, this paper argues that a more complex understanding of "the state" that civil society groups encounter can enrich our understanding of both civil society and the multilevel Chinese state in two ways. First, a more nuanced understanding of the individuals who make up the local state - and their professional incentives for partnering with or avoiding non-state actors - can be a useful complement to existing research on regional and sectoral variation in the

9 Interview with county official, Yunnan, 2011. 
regulation of NGOs. ${ }^{10}$ Second, existing research on local governance and officials' promotion incentives has paid scant attention to non-state groups. My research suggests that, as local governments increasingly partner with non-state groups to provide public services, ${ }^{11}$ these groups are becoming a tool that ambitious officials strategically mobilize in order to improve their own promotion prospects. Case studies of two organizations, which possessed varying levels of local knowledge and support but looked quite similar in terms of their relationships with different types of officials, demonstrate the utility of analysing organizations' relationships with these different types of officials.

\section{Existing Literature}

The concept of civil society has been a topic of contention among China scholars since the Tiananmen Square democracy movement in 1989. Much of this research has been concerned with whether "civil society" exists in China. ${ }^{12}$ As civil society organizations have proliferated - the number of officially registered NGOs rose from 4,446 in 1988 to 506,173 in 2013 - the stakes of these debates have increased. ${ }^{13}$ The answers have also become more complex as new organizational forms - for instance, GONGOs (government-organized NGOs, guanban feizhengfu zuzhi 官办非政府组织), PONGOs (Party-organized NGOs, dangban 党办 NGO), and QUANGOS (quasi-autonomous NGOs, banzizhi 半自治 NGO) - have blurred the distinction between state and society. ${ }^{14}$ The multitude of ways in which the Chinese state interacts with these actors - repression and surveillance, regulation, outsourcing of public services - has grown increasingly diverse as well. ${ }^{15}$

At stake in much of the existing literature is the possibility of an autonomous civil society that can serve as a counterweight to the CCP regime. Some scholars argue that social organizations are able to create substantial autonomy, ${ }^{16}$ but a growing consensus regards autonomy as a virtually impossible standard for Chinese organizations. And while disruption and repression by state actors are real concerns, these organizations often see autonomy from the state as an undesirable outcome because autonomy would likely come at a cost to the organization's influence, access or perceived legitimacy. ${ }^{17}$ This is certainly not true of all organizations - some grassroots organizations try to avoid the state, and some groups even try to hide the fact that they are acting in concert. ${ }^{18}$ Given this lack

10 Hildebrandt 2013; Teets 2015.

11 Jing 2008; Jing and Savas 2009; Simon and Teets 2014; Teets 2012; Zhang, Mengzhong, and Sun 2012.

12 Chamberlain 1993; Hsu, Carolyn 2010; Huang 1993; Salmenkari 2008; 2011; 2013; White 1993.

13 Spires, Tan and Chan 2014, 65.

14 Lee and Wang 2005; Saich 2000; Schwartz 2004; Simon 2013; Thornton 2013; Wu 2003.

15 Fu 2016; Hildebrandt 2011; Howell 2015; Jing 2008; Jing and Savas 2009; Kang and Han 2008; Simon and Teets 2014; Teets 2012; Yang 2003; Zhang, Mengzhong, and Sun 2012.

16 Zhang, Xin, and Baum 2004.

17 Foster 2001; Gallagher 2004; Hsu, Carolyn 2008; Hsu, Jennifer, and Hasmath 2014; Saich 2000; Spires 2011.

$18 \mathrm{Fu} 2016$. 
of agreement over the desirability and feasibility of autonomy from the state, then, it seems more useful to characterize the various roles that the state plays vis-à-vis social organizations, and to find more accurate frameworks for making sense of the relationship between the state and civil society.

The dominant approach to understanding the relationship between the state and civil society groups in China is the corporatist model. Corporatism describes a mode of interest representation under which different interest groups are channelled into hierarchically organized associations responsible for negotiating with the state on behalf of the interest group they represent. ${ }^{19}$ Although China diverges from the orthodox corporatist model, scholars have applied it to China since the onset of its associational revolution. ${ }^{20}$ More recently, Jennifer Hsu and Reza Hasmath have claimed that local governments use a corporatist model to encourage civic organizations to provide public services in support of the goals of the local state. ${ }^{21}$ Jude Howell describes the state's attempts to work with labour NGOs in order to provide public services to migrant workers as "welfarist incorporation." 22 However, the corporatist model has been critiqued for ignoring the ways in which the market shapes the environment in which NGOs function, ${ }^{23}$ and for only describing those organizations that are closely linked to the state. ${ }^{24}$

Furthermore, and most importantly for this paper, the corporatism literature focuses primarily on hierarchical relationships between state agencies and social organizations. Although the corporatism literature has improved on autonomyfocused research in its more complex and internally varied picture of "the state," the literature still primarily regards the state as a set of functionally or geographically defined units, and it pays insufficient attention both to the individuals who make up the local state and to their rationale for assisting or hindering the work of NGOs. The evidence presented in this paper suggests that differently positioned representatives of the local state may diverge in their attitudes towards a single NGO.

A third set of sources provides something of a middle ground between the autonomy and corporatism schools. Jessica Teets argues that while the corporatist model may have applied to Chinese civil society in the 1990s, Chinese civil society is now characterized by a mix of autonomy and top-down linkages to the state ("consultative authoritarianism"). ${ }^{25}$ These links enable civil society groups to influence policymakers' perceptions of social problems - and ultimately the policy solutions they enact. ${ }^{26}$ Anthony Spires similarly sees the Chinese state

19 Schmitter 1979.

20 Dickson 2000-2001; Foster 2001; Unger and Chan 1995. Yep 2000 sounds a note of caution.

21 Hsu, Jennifer, and Hasmath 2014.

22 Howell 2015.

23 Howell 2012.

24 Spires 2011.

25 Teets 2013; 2014.

26 Teets 2016. 
and civil society groups as interdependent and engaged in "contingent symbiosis": state actors tolerate the presence of illegal organizations if they are able to claim credit for those organizations' achievements. ${ }^{27}$ And a new body of work on isomorphic pressures and organizational fields helps us to gain a better understanding of why some organizations pursue closer ties with the local state than others, and why the local state may better understand NGOs in some circumstances than others. ${ }^{28}$

While these new sources explore variation in non-state organizations' locations, the professional backgrounds of their founders and their resource strategies, I argue that they must be complemented by detailed attention to the individuals who make up the Chinese state. While a large body of work has described the varying behaviour of officials at different levels of the Chinese party-state hierarchy and across different agencies at the same level, ${ }^{29}$ this complex picture of the state - and particularly of the individual-level incentive structures that drive officials to act in different ways - is largely absent from the research on Chinese civil society. Furthermore, scholars have attributed both the CCP's political and economic strength and some of China's most intractable governance problems to the career incentives used to motivate individual officials. ${ }^{30}$ However, whether these incentives motivate officials to work with civil society groups remains largely unexplored.

\section{Data}

This paper draws on 65 interviews with NGO employees, experts, and county and township government officials. The civil society actors I interviewed worked for a range of organizations; while none sought to challenge the state, some were unregistered while others were registered GONGOs founded by lifelong government employees. These interviews were conducted between 2009 and 2012 as part of a broader project on public service provision in ethnically diverse areas of rural China. As a result, all of the organizations discussed in this article were involved in health-related and education-related programming, or in infrastructure construction, and implemented many of their programmes in resource-poor areas. I also rely on observations collected during non-participant observation of two NGOs engaged in the direct provision of health and education services in southwestern China, EdJustice and the Center for Community Empowerment (CCE). ${ }^{31}$ Both were founded by private individuals and both had strong relationships with local officials. One organization had foreign founders, while the other was founded by a successful member of the local elite. Despite this key difference,

27 Spires 2011.

28 Hasmath and Hsu 2014; Hsu, Carolyn, and Jiang 2015; Hsu, Jennifer, Hsu and Hasmath 2017.

29 Heberer and Schubert 2012; Lieberthal and Lampton 1992; Mertha 2009; Smith 2010.

30 Chung 2016; Edin 2003a; 2003b; Heberer and Schubert 2012; Landry 2008; O'Brien and Li 1999.

31 To protect identities, I use pseudonyms for all interviewees, individuals, places and organizations throughout. 
which gave the two organizations varying degrees of local knowledge and different resource bases, there were strong similarities in their relationships with local officials. This should increase our confidence in the broader relevance of the dynamics described in this article.

The argument of this article should not be presumed to apply to all Chinese NGOs. Rather, it is most applicable to those that employ what Carolyn Hsu and Yuzhou Jiang call a "state alliance" (as opposed to "state avoidance") strategy. ${ }^{32}$ Because the organizations I study focus on public service provision, their goals typically align quite well with those of local governments. Furthermore, these organizations were all either based in the ethnically diverse south-west or else ran programmes in ethnic minority areas, which were typically also resourcepoor; the dynamics I describe here might not apply to areas where local officials have less need for the material resources that NGOs could supply. The scholarly literature on promotion incentives and local official behaviour describes sufficiently consistent nationwide dynamics to suggest that the basic dynamics described here should hold in other regions of China as well. That said, the importance of regional variation in civil society management should not be understated, ${ }^{33}$ and it may be difficult for NGOs to develop relationships with innovators in places where these organizations are either less necessary or more politically sensitive than the areas I studied.

\section{Innovators}

Prior research suggests that Chinese officials are highly responsive, in both positive and negative ways, to the performance targets set for them by higher levels of government. Since cooperation with NGOs is not explicitly rewarded in the monitoring and promotion system for local officials, one might expect the cadre responsibility system to have little bearing on officials' interactions with civil society groups. On the contrary, however, my interviews suggest that the same political incentives that drive local officials in other contexts colour these officials' attitudes towards non-state organizations as well. The head of a Yunnan-based public health organization with programmes in several minority autonomous areas argued, for instance, that local officials always "look up": that is, they take action only when doing something increases their performance score and their likelihood of promotion. ${ }^{34}$ While scholars often assume that economic growth and social stability are the primary goals that local officials seek to achieve, these officials' superiors are now sufficiently interested in social service provision that "political achievements" such as decreasing the local HIV infection rate and engaging volunteers to provide public services are worth their while as well. As a result, local officials may be willing to work with NGOs

34 Interview with head of local public health NGO, Yunnan, 2010. 
whose work promotes these goals. ${ }^{35}$ More broadly, creativity and innovation can earn officials the positive attention of their superiors and improve their promotion prospects. As the head of a local GONGO told me, all officials want to do something "creative" to show off to higher-level officials in the hope of earning a promotion; implementing an innovative programme, such as working with a non-state organization to provide services to citizens in a new way, is one way of doing this. ${ }^{36}$

For these innovators - that is, the officials interested in spearheading new programmes in order to boost their own promotion prospects - working with NGOs may be a logical approach. ${ }^{37}$ Employees of foreign NGOs, domestic NGOs and GONGOs all frequently describe their primary contribution as an ability to experiment with new approaches to public service provision. Because these organizations are often small and resource-constrained, running experimental pilot programmes is often all they can afford to do; they have to simply hope that if a pilot programme is successful, the local government will take over the programme and implement it on a larger scale. ${ }^{38}$ Indeed, government adoption of an experimental programme is the best evidence, according to one local GONGO, that a programme has been successful. ${ }^{39}$ Whereas local officials are often risk averse and unwilling to try new approaches unless their success is virtually guaranteed, non-state service providers are willing to try new things, sometimes even knowing that they may fail. And they often do so with the tacit support of the local government, which wants to see whether new approaches to public service provision will work but does not want to assume direct responsibility for these experiments. ${ }^{40}$

In the service of enabling these experiments to succeed, promotion-minded officials provide substantial support to NGOs, far more than existing literature would lead us to believe. EdJustice, an educational NGO established by foreigners but with significant support from Chinese elites, provides a useful example of this dynamic. ${ }^{41}$ EdJustice depended heavily on the support of a single prefectural official, described by the organization's director as the "hook in the wall" on which all of the organization's programmes and relationships hung. In an influential provincial-level position when the organization's founders first met him,

35 Interview with local employee of international NGO, Beijing, 2010; interview with academic expert on civil society, Hong Kong, 2010.

36 Interview with head of local GONGO, Yunnan, 2010.

37 Working closely with NGOs is unlikely to be the only action these officials take to distinguish themselves as innovators; energetic and promotion-oriented, they pursue multiple types of innovation in an effort to attract the attention of their supervisors (interview with director of EdJustice, Beijing, 2011). The claim of this article is not that working with an NGO causes officials to be promoted, but rather that "innovator" officials perceive NGOs as one tool they can use to improve promotion prospects, and this perception shapes their interactions with non-state actors.

38 Interview with head of CCE, Sichuan, 2010. Several of the interviewees quoted in Hsu, Carolyn, and Jiang 2015 make similar claims.

39 Interview, head of local GONGO.

40 Interview, head of local public health NGO.

41 Interview, director of EdJustice. 
the official was later sent to the countryside to serve as Party secretary of Bright Sun, a poor prefecture-level city. Given three to five years to "revolutionize" Bright Sun - an achievement that would likely earn him a promotion - Party secretary Yao sought to partner with the NGO to bring new resources and an innovative new approach to improving educational outcomes in Bright Sun.

In some ways, the dynamic between Yao and EdJustice seems consistent with Spires's credit-claiming story. ${ }^{42}$ Yao stood to benefit from positive attention from higher-level officials should EdJustice succeed in improving the prefecture's educational outcomes, through very little effort of his own. Yao's interest in the partnership was not purely about claiming credit for others' work, however. Yao is one of a class of officials who are "ambitious, smart, interested in the welfare of the people they serve, and interested in new models." 43 He pushed the organization to expand their programmes more broadly than they would have done otherwise, a strategy that could backfire but one that made sense for an upwardly mobile official intent on seeking credit for initiating large-scale educational reform. He also ensured that the prefectural education bureau committed resources to help the organization's programmes succeed, including funding for assisting with volunteer placement and substantial logistical support from education bureau officials.

While Party secretary Yao was an especially active partner, EdJustice relied on a similar partnership with an entrepreneurial county leader, Governor Zhang, at a second project site, Cloud Forest County (located outside Bright Sun Prefecture) as well. While many county leaders were nervous about partnering with a non-state organization, Governor Zhang pushed the partnership through "by sheer force of personality," although he was not the organization's only advocate (the vice-chief of the education bureau was also supportive of the organization). While Governor Zhang did not provide the same level of material support to the organization that it received in Bright Sun Prefecture, his willingness to actively support the organization, and to task the education bureau with providing logistical support, made it possible for EdJustice to operate in the county. Indeed, the presence of a supportive "innovator" in Governor Zhang was one of the reasons that EdJustice chose to operate in the county in the first place.

In addition to material support, innovators aid NGOs by providing access to the cellular structure of the Chinese state. ${ }^{44}$ While organizations' ties to the state are often contingent and personalistic, for instance based on a friendship or a serendipitous meeting with a single official, ${ }^{45}$ officials are embedded in horizontal, place-based networks as well as vertical, issue-area based ones (the tiao/kuai system). By providing access to both types of networks, officials who serve as active partners to non-state service providers can enable organizations to work in a

45 Interview, director of EdJustice; interview with head of foreign NGO, Yunnan, 2010. 
broader set of locations and to make their programmes more ambitious than would otherwise be possible.

One Sichuan-based NGO provides a useful example of the ways in which the active partnership of a single bureau can spawn a broader network of ties to different levels of government and to offices organized around different issue areas, and ultimately improve an organization's efficacy. The organization, the Center for Community Empowerment (CCE), runs a variety of education, health and economic development programmes in several ethnically diverse counties, many of which are also among the poorest counties in the province. Because of its emphasis on helping women and girls, the organization's strongest ties are to the women's federation (fulian 妇联) at the prefectural level. The vertical hierarchy of the fulian has given the organization access to county-level partners (each county has a fulian branch) and has assured the organization assistance from townships and villages officials because the county fulian maintains close ties to female cadres at these levels. ${ }^{46}$ Without access to this vertical network, CCE would have difficulty implementing its programmes. ${ }^{47}$

The prefectural fulian's horizontal linkages to other issue-based offices at the same geographic level in the administrative hierarchy were also a valuable resource for CCE. Most importantly, the prefectural fulian introduced CCE to officials from the prefectural labour bureau. This led to a partnership under which the labour bureau introduced girls who had graduated from CCE's work training programme to prospective employers both within Sichuan (hotels, restaurants and tourism companies) and outside the province (factories in coastal cities). This was a mutually beneficial arrangement. As the organization initially struggled to convince "impatient" girls to finish the extensive training, the promise of reliable work opportunities provided an incentive for participants to complete the programme, which helped the organization accomplish its goals and made it a more attractive candidate for foreign foundation funding. For the labour bureau, tasked in part with providing workers to employers in coastal cities, CCE provided a steady stream of relatively well-prepared potential workers in an area where most residents' poor Mandarin and limited education inhibited their ability to succeed outside their villages. ${ }^{48}$

These productive partnerships with innovators complicate the notion that autonomy is a desirable goal for NGOs. Employees certainly express some frustration with these relationships to which they often believe they make an unequal contribution. One employee of a public health NGO complained that NGOs are "paying for their own programmes and paying the government for the privilege

46 Interview with local employee of CCE, Sichuan, 2010.

47 This phenomenon is not limited to CCE. The head of a local NGO in Yunnan also described these vertical networks as essential: without them, organizations would need to build new relationships at each level of government. Building ties with one bureau at the provincial or prefectural level enabled easy access to lower-level offices. Interview with director of local NGO, Yunnan, 2010.

48 Interview, local employee of international NGO, Beijing. 
of being able to implement them." 49 Another argued that NGOs are legitimate in a way that the local state is not: "We solve the problems [the government] hasn't solved." ${ }^{50}$ Despite these frustrations, however, organizations often have little choice but to work closely with the state, and many would not want to avoid such a partnership even if they could. Somewhat paradoxically, partnering with officials can provide organizations with legitimacy in the eyes of the citizens they hope to serve. Citizens largely distrust Chinese NGOs; their trust in NGOs has remained lower than their trust in the government, even as awareness of local and central government corruption has increased. ${ }^{51}$ Unsurprisingly, organizations respond to these dynamics by tying themselves more closely to the Chinese state. One study of the Chinese NGO Project Hope argues that NGO staff intentionally "blurred the distinction between their charitable organization and the state." 52 The head of CCE argued that without the partnership of officials from the fulian, it might have been difficult to recruit girls to participate in one of the organization's training programmes, as many citizens regard NGOs with some suspicion. ${ }^{53}$ Organizations that try to operate independently from the state often face harassment by government officials and scepticism from citizens who are wary of complicating their own relationship with local government. ${ }^{54}$ Given these dynamics, it is hardly surprising that many organizations see a partnership with an innovator as an essential tool for organizational success.

Organizations do incur two types of costs by depending heavily on these relationships, however. First, their lack of autonomy from innovator officials means that the spatial distribution of NGO projects often reflects officials' preferences, based largely on what will improve their promotion prospects, rather than the organization's mission. Like many non-state organizations operating in China, EdJustice explicitly sought to ameliorate the inequitable distribution of resources between rural and urban areas. Insofar as Bright Sun contains several poor counties with large minority populations and is located in one of China's poorest provinces, the partnership with Secretary Yao has helped the organization to successfully pursue this goal. However, EdJustice was given limited discretion over the localities in which it operated. Although the director described the process of choosing county work sites within Bright Sun as a "process of negotiation" between the organization and their partners in the prefectural government, EdJustice was bargaining from a position of weakness given its dependence on these government ties. Thus, despite the organization's rural and egalitarian focus, it began by implementing its programmes in counties close to the prefectural capital and even one in the prefectural capital, which is a developed city relative to the surrounding rural areas, in order to give face to

\footnotetext{
49 Interview with employee of foreign public health NGO, Yunnan, 2010.

50 Interview, head of CCE.

51 Dickson 2016.

52 Hsu, Carolyn 2008, 89

53 Interview, head of CCE.

54 Interview with head of local NGO, Yunnan, 2010.
} 
prefectural officials from Bright Sun. ${ }^{55}$ Other organizations have even less input than EdJustice had over the location of its projects. According to an employee of an international development organization with several programmes in minority areas throughout China, the organization's high-level government partners exert complete control over the spatial distribution of the organization's programmes. The organization works closely with the poverty alleviation bureau (fupinban 扶 贫办) and said that the national fupinban typically directed the organization to work with a given provincial poverty alleviation office, which in turn would specify a list of counties to work in within the province. My interviewee did not see this dynamic as problematic, claiming that "the best way to help the Chinese government [phrasing she later changed to "the Chinese people"] is to go where the government says the need is greatest." 56

Innovator officials have incentives to place programmes in certain types of localities for reasons other than the severity of the area's need. Inducing EdJustice to work with schools in the Bright Sun prefectural capital ensured that Secretary Yao's innovative approach to educational reform would be observed by the higher-level officials in charge of monitoring his performance and recommending him for promotion. Should the organization have operated far from the prefectural capital, in the types of locales the organization originally set out to serve, this would not necessarily have been the case. Prefectural capitals and other nearby areas are also the places where a leader like Secretary Yao, brought in from elsewhere with few local ties, must forge a support base in the local political elite in order to do his job effectively. Agreeing to serve these relatively proximate areas increased EdJustice's political value to Bright Sun officials (including Yao); however, it also meant that relatively well-off areas of the prefecture - those already privileged by geographic proximity to political elites - received a disproportionate share of the organization's services. ${ }^{57}$ The organization was able to push back against officials' preferences to some degree - it refused to work in one proposed project site that was clearly not in need of additional resources - but it could not assert its own demands too strongly without jeopardizing its important relationships with its backers. ${ }^{58}$

These spatial dynamics are not inevitable. For example, CCE was able to operate in the counties it saw as the most needy, rather than relying on prefectural officials to determine where the organization would operate. But CCE also had unusually strong local knowledge and support that made this possible: the organization's founder was from the prefecture and had strong personal ties to local elites, and nearly all the staff had grown up in the area. For many organizations that lack this local knowledge base, the information that officials can provide is a resource essential to the success of their programmes, but dependence on

55 Interview, director of EdJustice.

56 Interview with employee of international development NGO, Beijing, 2011.

57 The spatial logic underpinning promotion incentives leads officials to prioritize direct provision of public services to these same proximate areas. Newland 2015.

58 Interview, director of EdJustice. 
this information also makes their programmes vulnerable to the same biases, spatial and otherwise, that inform those officials' performance of their own duties.

A second cost to relying on innovators is that doing so can imperil an organization's long-term position. By depending on innovators, organizations are tied to temporary residents of the places where they operate, since these officials typically have their eye on their next promotion up and out of their current locality or position. Once these officials move on to the next position, organizations may find it difficult to function effectively. EdJustice, for instance, encountered difficulties when the supportive vice-head of the county education bureau in Cloud Forest County was promoted to a position in the prefectural government. ${ }^{59}$ This is not especially surprising; the education bureau official was likely supportive of EdJustice in the first place in part because he saw the organization as a tool to improve his own promotion prospects. Organizations thus face a difficult dilemma. They often choose where to operate because they have the support of innovative, open-minded (kaifang 开放) leaders in those localities, ${ }^{60}$ but those leaders are unlikely to stay put; the very qualities that make them good partners for NGOs also make them good candidates for promotion.

EdJustice used a variety of strategies to shelter the organization from the departure of a supportive innovator. Describing efforts to move away from personalistic ties to individual leaders towards more programmatic ties as "difficult but necessary," the organization's leaders pursued a dual strategy of attempting to formalize their relationships with supportive organizations at universities and in the provincial education bureau while simultaneously fostering personal ties to individual leaders by doing favours for those leaders and pursuing personal connections with other VIPs who could potentially assist the organization. Because formal agreements (such as a memorandum of understanding with an office within the education bureau) were only implemented when supportive innovators put pressure on a particular government office, ${ }^{61}$ the two strategies were not substitutes for each other, and the organization was likely to continue to depend on individual relationships with officials even as its formal bureaucratic ties deepened.

\section{Implementers}

What about organizations' relationships with the officials who do stay put? Although much is made of promotion incentives in the Chinese politics literature, only a handful of the officials I encountered during my fieldwork seemed eager to move up the party-state hierarchy. As one Yunnan county official explained to me, most officials he knows just want a comfortable life in their home county, without the pressure and move away from family that a promotion typically

59 Ibid.

60 Interview, head of local GONGO; interview, local employee of international NGO, Beijing.

61 Interview, director of EdJustice. 
entails. ${ }^{62}$ Indeed, the officials I refer to as "implementers" - typically long-term employees of a single bureau with little interest in a rapid ascent - make up a substantial proportion of local officialdom and represent a different facet of the local state that NGOs encounter. Relationships with these implementers pose a different set of challenges than ones with innovators. Without a strong personal career incentive to motivate cooperation, implementers are often reluctant to work closely with non-state organizations. Organizations must build partnerships with officials who vary dramatically in their enthusiasm, aversion to risk and commitment to an organization's goals. These challenges are a result of the principal-agent problems created by the multilevel structure of the Chinese state. There is no guarantee that an innovator's commitment to cooperation with a civil society organization is shared by the officials he supervises; facing different incentives and time horizons, these lower-level officials cannot easily be forced to actively cooperate with organizations they are sceptical about.

Once an organization has established a relationship with an innovator, it typically relies on a web of lower-level officials to help implement its programmes. In the case of CCE, the organization's partners in the prefectural women's bureau connected the organization to county-level women's bureau officials, who in turn helped to recruit female township and village officials to assist with the direct implementation of CCE's programmes. For example, CCE ran HIV/ AIDS-prevention education programmes for rural women and distributed free condoms to women who participated. Operating with a small number of staff who could not have easily conducted these training programmes on their own, CCE relied on the participation of these female local officials to amplify the organization's impact. In order to do this, CCE employees brought female township and village officials together for training; these officials were then tasked with returning to their home villages and replicating the training for female residents.

Without the partnership of these implementers, CCE would have been largely unable to run its programmes - a problem likely to be worse for organizations without the in-depth local knowledge and elite ties that CCE's leaders possessed. The first obstacle was organizational capacity: CCE fields a small staff and would have been unable to directly conduct training in many villages in a short period of time. Bringing local women together in a central location for training would also have been difficult, as transportation between villages is extremely poor and women belonging to the local ethnic minority group bear an unusually heavy workload. ${ }^{63}$ Even if their numbers had been greater, CCE staff would likely have been unable to conduct these training sessions with village women themselves owing to the local cultural norms (male employees could not have discussed sex with village women, for instance). Even female employees of the organization were regarded with suspicion as village outsiders; although they came from the same prefecture and belonged to the same ethnic group, they 
were more educated and far more assimilated into Han culture than the village women. In some villages, CCE employees had little difficulty interacting with local women who participated in CCE's programmes, but in others the women were reluctant even to participate in a follow-up survey conducted by these employees to evaluate the organization's programmes. ${ }^{64}$ The help of local female officials who were well known to village residents was thus essential to the organization's ability to reach a large number of citizens.

However, CCE's relationships with these implementers, although vital to the organization's success, were complicated. Some officials enthusiastically embraced the task of conducting training for local women, and the organization's follow-up surveys found local residents to be quite knowledgeable about HIV prevention. Other officials were the opposite: some simply failed to conduct the training at all, while others did so in such a cursory way that local women were unable to answer any basic questions about HIV prevention, to the frustration of CCE employees. As there was no viable alternative available, there was little the organization could do to force recalcitrant township and village officials to do a more thorough job of implementing the organization's training curriculum.

The grassroots officials with whom CCE partnered were not well positioned for promotion to higher levels of government, even if they had been interested in moving up (many were functionally illiterate and spoke no Mandarin Chinese, for instance). They thus did not have the same career incentives as innovators when it came to participating in the implementation of an innovative programme. Whether they worked hard to achieve the organization's goals seemed to be more a matter of personal interest in the organization's work than a rational calculation. The head of one GONGO claimed that when a higher-level official orders lower-level officials to do something, they do it. This was a huge benefit of partnering with an innovator in a position to assign tasks to lower-level officials. ${ }^{65}$ Perhaps GONGOs, owing to their relatively close ties to the state, are better able to get their high-level backers to put pressure on lower-level implementers on their behalf. The CCE example, however, suggests principal-agent problems can be severe; even when implementers dutifully assist with a programme, they may do so in ways that undermine the organization's effectiveness. One of their primary benefits as partners - their embeddedness in the local community, in contrast to innovator officials who often parachute in from elsewhere - can be a double-edged sword. Implementers may have strong opinions and preferences regarding the needs of their community that do not necessarily accord with the organization's philosophy.

The nature of EdJustice's partnerships with implementers was somewhat different, but the two organizations faced similar challenges as a result of the disconnect between innovators' goals and those of implementers. After building a 
relationship with an innovator in a high-level leadership position in each of its sites, the organization worked most directly with the prefectural and county education bureaus. Even though these bureaus' superiors were enthusiastic supporters of the organization, these relationships were somewhat fraught. Education bureau officials had little to gain and much to lose by forging overly close ties with the organization; whereas the innovator could distance himself from the organization should it get into political or other trouble - education was only one part of his broad portfolio - education bureau officials would likely be unable to avoid taking responsibility and could face a substantial career penalty. ${ }^{66}$ And while high-risk, high-reward gambles are sometimes worthwhile for officials looking to stand out from a crowd, as innovators tend to do, there is little benefit to risk-taking for officials simply looking to maintain stable employment in their current position.

When it comes to partnering with implementers, then, organizations may thus find themselves (and their innovator partners) simply ignored. EdJustice established a relationship with the international office of the provincial education department and brought an official from that department to Cloud Forest County to encourage teachers to incorporate more creative methods for teaching spoken English into their classrooms. Because teachers were evaluated on the basis of their students' test scores rather than on their spoken English, however, neither the official nor EdJustice could successfully convince local teachers to make spoken English a priority. ${ }^{67}$

As with the case of non-state organizations' relationships with innovators, these relationships with implementers complicate the notion of organizational autonomy, calling into question whether such autonomy is either possible or desirable. Although organizational leaders and employees frequently expressed frustration with do-nothing local officials, in the multilevel Chinese system, under which interaction with these officials was essentially unavoidable, these organizations often wanted more involvement than local officials were willing to provide, not less. ${ }^{68}$

\section{Conclusion}

This paper argues for shifting our attention away from organizational autonomy, which the examples presented here suggest is neither possible nor desirable, to a more detailed investigation of organizational dependence on individual officials. The state, as China's NGOs experience it, is multifaceted: it contains not only

66 Interview, director of EdJustice.

67 Ibid.

68 Exceptions include cases where the government is distrusted by the population an organization serves. For a public health organization serving IV drug users, for instance, the most helpful support that the government partner (the local CDC) provided was to secure a promise from the public security bureau to refrain from arresting programme participants. Interview with employee of international public health organization, Yunnan, 2010. 
laws and bureaus but also self-interested individuals who seek to achieve their own goals within the strictures of a complex, multilevel bureaucracy. Different types of officials face different career incentives: innovators seek to draw attention through entrepreneurial governance strategies (and thus to maximize their own promotion prospects), while implementers seek to minimize political risk and avoid spending time on innovators' pet projects that are unlikely to benefit them personally. As non-state organizations seek to function in a multilevel system in which the innovators often oversee the implementers, they often benefit from close ties to the first group and struggle to overcome the second group's reluctance to engage with them. This suggests that organizations often do not see autonomy as a valuable asset. Close integration with the local state comes at a cost, however. First, it means that organizations are often deployed in support of officials' goals in much the same way that discretionary government projects can be, with the result that non-state organizations' programmes often exhibit the same kinds of spatial and other biases that government services do. And, second, close ties to innovator officials can leave organizations in a weak long-term position. These officials are often deployed only temporarily to a given locale, and without support from the implementers who stay behind, the organization's viability is unlikely to outlast the tenure of its primary backer.

Recent changes to the legal environment in which China's civil society organizations function may alter the dynamics described in this article, but they are unlikely to undermine them completely. While some hope that the Charity Law (implemented on 1 September 2016) will produce benefits for NGOs, such as greater ease of registration, there are also concerns that parts of the law, such as the "social ethics" (shehui gongde 社会公德) provisions, are dangerously ambiguous. ${ }^{69}$ Many see the Overseas NGO Law (1 January 2017) as repressive, as it subjects organizations to stricter registration requirements and to monitoring by the Ministry of Public Security. ${ }^{70}$ While it is still too early to assess the longterm effects of these policy changes, one possibility is that they will make it more difficult for NGOs to secure the backing of innovators for two reasons. First, NGOs are useful to these promotion-oriented officials in part because of the resources they can bring to cash-strapped areas. New restrictions on foreign funding are likely to affect these organizations - both CCE and EdJustice depend on support from foreign foundations, for instance - and may make them less useful partners to officials intent on rapid implementation of programmes that will earn them positive attention from their superiors. Second, if the purpose of the new laws is (in part) to subject NGOs to more systematic and formal oversight, their interactions with supervising bureaus may now leave fewer opportunities

69 Santos 2016; “Guanyu 'Zhonghua renmin gongheguo cishanfa' (zaoan) (er ci shenyi gaoxiu gaigao) de yijian fankui" (Grassroots NGOs' feedback on the draft law), on Anthony J. Spires' website at http:// anthonyjspires.weebly.com/charity-law-in-china.html. Accessed 5 January 2017.

70 Wong 2016. 
for personal, relatively informal relationships between individual innovators and NGOs to develop.

However, it is unlikely that the dynamics described in this article will disappear completely. NGOs in China have always operated in (and despite) an unfavourable legal environment, so the new laws may mark less of a radical departure than early commentary suggests. It is possible that by clarifying what is and is not permitted, the new laws will actually make it easier for NGOs to function in China. ${ }^{71}$ Furthermore, the findings of this article are consistent with the claim by Hsu and Teets that officials and bureaus develop a vested interest in the success of the NGOs on which they depend. ${ }^{72}$ As long as innovator officials see partnerships with NGOs as a pathway to promotion, they are likely to protect and continue to work with the organizations that can bring them benefit. Without fundamental changes to the evaluation and promotion system for local officials, this dynamic is unlikely to change.

\title{
Acknowledgement
}

For helpful comments on this article and earlier versions of the project, the author thanks Roselyn Hsueh, Kyle Jaros, John Chung-En Liu and Kevin O'Brien. This project was funded by the National Science Foundation (Doctoral Dissertation Improvement Grant SES-1023953), the UC-Berkeley Center for Chinese Studies, and the UC-Berkeley Institute for International Studies.

\section{Biographical note}

Sara A. Newland is China public policy postdoctoral fellow at the Ash Center for Democratic Governance and Innovation, Harvard Kennedy School. From autumn 2018, she will be an assistant professor of government at Smith College.

\begin{abstract}
摘要：中国公民社会的研究常聚焦于社会组织相对于政府的自主性，然而， 组织依靠政府与个别干部的具体方式还有待进一步鳌清。本研究指出, 干部 个人的工作升迁诱因在非政府组织和政府的关系中扮演重要角色。所谓的 革新者为寻求快速升迁而选择与公民社会合作以得到上级政府的关注。为 了达到个人的工作目标, 革新者支持非政府组织。但是过度依赖革新者的组 织也面临一些问题: 它们常因此偏离组织使命而不利在当地的长期发展。另 一种干部算是执行者。执行者比较重视稳定和安全。虽然上级有时候会勉 强他们与非政府组织合作，但是执行者清楚这种伙伴关系的风险，而认为这 种合作没有个人的利益。这些结论凸显了中国多层次政府架构对于国家-社 会关系的重要性。
\end{abstract}

关键词: 公民社会; 非政府组织; 多层次治理; 干部管理; 中国农村; 公共服务 


\section{References}

Burns, John. 1985-1986. "Local cadre accommodation to the 'responsibility system' in rural China." Pacific Affairs 58(4), 607-625.

Chamberlain, Heath. 1993. "On the search for civil society in China." Modern China 19(2), 199-215. Chung, Jae Ho. 2016. "China's local governance in perspective." The China Journal 75, 38-60.

Dickson, Bruce. 2000-2001. "Cooptation and corporatism in China." Political Science Quarterly 115 (4), 517-540.

Dickson, Bruce. 2016. "The Xi Jinping administration: a comprehensive assessment." Roundtable at the Association for Asian Studies Annual Meeting, Seattle, WA, 31 March-3 April.

Edin, Maria. 2003a. "State capacity and local agent control in China." The China Quarterly 173, 3552.

Edin, Maria. 2003b. "Remaking the Communist Party-State." China: An International Journal 1(1), $1-15$.

Foster, Ken. 2001. "Associations in the embrace of an authoritarian state." Studies in Comparative International Development 35(4), 84-109.

Fu, Diana. 2016. "Disguised collective action in China." Comparative Political Studies 50(4), 499-527.

Gallagher, Mary. 2004. "China: the limits of civil society in a late Leninist state." In Muthiah Alagappa (ed.), Civil Society and Political Change in Asia. Stanford, CA: Stanford University Press, 419-452.

Hasmath, Reza, and Jennifer Y.J. Hsu. 2014. "Isomorphic pressures, epistemic communities and state-NGO collaboration in China." The China Quarterly 220, 936-954.

Heberer, Thomas, and Gunter Schubert. 2012. "County and township cadres as a strategic group." Chinese Journal of Political Science 17(3), 221-249.

Hildebrandt, Timothy. 2011. "The political economy of social organization registration in China." The China Quarterly 208, 970-989.

Hildebrandt, Timothy. 2013. Social Organizations and the Authoritarian State in China. New York: Cambridge University Press.

Howell, Jude. 2012. "Civil society, corporatism and capitalism in China." Journal of Comparative Asian Development 11(2), 271-297.

Howell, Jude. 2015. "Shall we dance? Welfarist incorporation and the politics of state-labour NGO relations." The China Quarterly 223, 702-723.

Hsu, Carolyn L. 2008. "'Rehabilitating charity' in China: the case of Project Hope and the rise of nonprofit organizations." Journal of Civil Society 4(2), 81-96.

Hsu, Carolyn L. 2010. "Beyond civil society.” Journal of Civil Society 6(3), 259-277.

Hsu, Carolyn L., and Yuzhou Jiang. 2015. "An institutional approach to Chinese NGOs." The China Quarterly 221, 100-122.

Hsu, Carolyn L., and Jessica C. Teets. 2016. "Is China's new overseas NGO management law sounding the death knell for civil society? Maybe not." Asia-Pacific Journal 14(3), 1-14.

Hsu, Jennifer Y.J., and Reza Hasmath. 2014. "The local corporatist state and NGO relations in China." Journal of Contemporary China 23(87), 516-534.

Hsu, Jennifer Y.J., Carolyn L. Hsu and Reza Hasmath. 2017. "NGO strategies in an authoritarian context, and their implications for citizenship: the case of the People's Republic of China." Voluntas 28(3), 1157-79.

Huang, Philip. 1993. "'Public sphere'/civil society' in China?” Modern China 19(2), 216-240.

Jing, Yijia. 2008. "Outsourcing in China." Public Administration and Development 28, 119-128.

Jing, Yijia, and E.S. Savas. 2009. "Managing collaborative service delivery: comparing China and the United States." Public Administration Review 69(s1), S101-S107.

Kang, Xiaoguang, and Heng Han. 2008. "Graduated controls: the state-society relationship in contemporary China." Modern China 34(1), 36-55.

Landry, Pierre. 2008. Decentralized Authoritarianism in China. New York: Cambridge University Press. 
Lee, Sang-Cheoul, and Yunxia Wang. 2005. "A study on the establishment and transformations of Chinese type QUANGOs." International Review of Public Administration 10(1), 45-57.

Lieberthal, Kenneth, and David Lampton (eds.). 1992. Bureaucracy, Politics, and Decision Making in Post-Mao China. Berkeley, CA: University of California Press.

Mertha, Andrew. 2005. "China's 'soft' centralization." The China Quarterly 184, 791-810.

Mertha, Andrew. 2009. "Fragmented authoritarianism 2.0." The China Quarterly 200, 995-1012.

Newland, Sara. 2015. "Diversity and Distribution: Essays on Local Governance and Public Service Provision in Multiethnic China." Ph.D. diss, University of California, Berkeley.

O'Brien, Kevin, and Lianjiang Li. 1999. "Selective policy implementation in rural China." Comparative Politics 31(2), 167-186.

Perry, Elizabeth. 1994. "Trends in the study of Chinese politics." The China Quarterly 139, 704-713.

Read, Benjamin. 2003. "Democratizing the neighbourhood?" The China Journal 49, 31-59.

Saich, Tony. 2000. "Negotiating the state: the development of social organizations in China." The China Quarterly 161, 124-141.

Salmenkari, Taru. 2008. "Searching for a Chinese civil society model." China Information 22(3), 397421.

Salmenkari, Taru. 2011. "Community building, civil society and societal service production in China." Journal of Civil Society 7(1), 101-118.

Salmenkari, Taru. 2013. "Theoretical poverty in the research on Chinese civil society." Modern Asian Studies 47(2), 682-711.

Salmenkari, Taru. 2014. "Encounters between Chinese NGOs and the state." Issues and Studies 50(2), $143-177$.

Santos, Lean Alfred. 2016. "Charity law signals growing role for NGOs in China," 11 April, https:/ www.devex.com/news/charity-law-signals-growing-role-for-ngos-in-china-87998. Accessed 11 April 2016.

Schmitter, Philippe. 1979. "Still a century of corporatism?" In Philippe Schmitter and Gerhard Lehmbruch (eds.), Trends toward Corporatist Intermediation. London: Sage, 85-129.

Schwartz, Jonathan. 2004. "Environmental NGOs in China." Pacific Affairs 77(1), 28-49.

Simon, Karla. 2013. Civil Society in China. New York: Oxford University Press.

Simon, Karla, and Jessica C. Teets. 2014. "Revolutionizing social service delivery in China: the new policy of 'contracting out' to non-profit organizations." International Journal of Civil Society Law $12(2), 28-66$.

Smith, Graham. 2010. "The hollow state: rural governance in China." The China Quarterly 203, 601618.

Spires, Anthony J. 2011. "Contingent symbiosis and civil society in an authoritarian state." American Journal of Sociology 117(1), 1-45.

Spires, Anthony J., Lin Tao and Kin-man Chan. 2014. "Societal support for China's grass-roots NGOs." The China Journal 71, 65-90.

Teets, Jessica C. 2012. "Reforming service delivery in China." Journal of Chinese Political Science 17, $15-32$.

Teets, Jessica C. 2013. "Let many civil societies bloom: the rise of consultative authoritarianism in China." The China Quarterly 213, 19-38.

Teets, Jessica C. 2014. Civil Society under Authoritarianism: The China Model. New York: Cambridge University Press.

Teets, Jessica C. 2015. "The evolution of civil society in Yunnan Province." Journal of Contemporary China 24(91), 158-175.

Teets, Jessica C. 2016. "Beyond corporatism: the role of civil society networks in changing environmental policy in China." Paper presented at the Association for Asian Studies Annual Meeting, Seattle, WA, 31 March-3 April.

Tenzin, Jinba. 2014. "A grassroots association on the Sino-Tibetan border." The China Quarterly 217, 99-120. 
Thornton, Patricia M. 2013. "The advance of the Party: transformation or takeover of urban grassroots society?" The China Quarterly 213, 1-18.

Unger, Jonathan (ed.). 2008. Associations and the Chinese State. Armonk, NY: M.E. Sharpe.

Unger, Jonathan, and Anita Chan. 1995. "China, corporatism, and the East Asian model." Australian Journal of Chinese Affairs 33, 29-53.

White, Gordon. 1993. "Prospects for civil society in China: a case study of Xiaoshan City." The Australian Journal of Chinese Affairs 29, 63-87.

Wong, Edward. 2016. "China reigns in foreign groups under new law," New York Times, 29 April.

Wu, Fengshi. 2003. "Environmental GONGO autonomy." The Good Society 12(1), 35-45.

Yang, Guobin. 2003. "The co-evolution of the internet and civil society in China." Asian Survey 43(3), 405-422.

Yep, Ray. 2000. "The limits of corporatism for understanding reforming China." Journal of Contemporary China 9(25), 547-566.

Zhang, Mengzhong, and Jian Sun. 2012. "Outsourcing in municipal governments.” Public Performance and Management Review 35(4), 696-726.

Zhang, Xin, and Richard Baum. 2004. "Civil society and the anatomy of a rural NGO." The China Journal 52, 97-107. 